\title{
УДК: 35.075.31(477)
}

DOI: https://doi.org/10.26661/hst-2020-6-83-13

\section{САМОРОЗВИТОК ОСОБИСТОСТІ КЕРІВНИКА ЯК ЛІДЕРА ІННОВАЦІЙ В УМОВАХ СИСТЕМНИХ ЗМІН}

\author{
(С) СТАРОДУБЕЦЬ, В. С. \\ кафедра менеджменту організацій та управління проектами \\ Інженерного навчально-наукового інституту Запорізького національного \\ університету(Запоріжжя, Україна) \\ E-mail: starodubecviktoria@gmail.com \\ ORCID iD: http://orcid.org/0000-0003-0395-2675 \\ Інженерний навчально-науковий інститут Запорізький національний університет, \\ пр.Соборний, 226, 69006 Запоріжжя, Україна \\ Engineering educational and scientific Institute of Zaporizhzhia National University, 226 \\ Soborny
}

\begin{abstract}
Анотація Актуальність роботи полягає в тому, що світова глобалізація та динамічний розвиток сучасного суспільства зумовили появу «smart-суспільства» як високорозумного і вискотехнологічного, яке характеризується безперервним розвитком інновацій, активне впровадження яких має великий вплив на економіку, процеси виробництва, культуру, освіту, побут, соціальну сферу, наукові дослідження. Управління інноваційною діяльністю та взаємодія 3 існуючими інноваційними технологіями стають невід'ємними компонентами управління організацією як соціально-економічною системою і підсистемами у вигляді структурних підрозділів, які вимагають креативних працівників, зданих працювати у конкурентоспроможному середовищі. Метою дослідження $є$ теоретичне обгрунтування інноваційної діяльності як чинника саморозвитку особистості керівника. Завдання дослідження та формування цілей статті: дослідити місце і роль керівника як стратегічного лідера команди; 3'ясувати розвиток особистості керівника як інноваційного лідера нового типу; виявити напрями інноваційної діяльності як чинника саморозвитку керівника в умовах системних змін та сформувати програму саморозвитку особистості керівника; обгрунтувати інноваційні технології у сфері менеджменту та необхідність їх впровадження в умовах smart-суспільства. Об'єктом дослідження виступає особистість керівника, як лідера інновацій та змін в умовах системних змін. Завдання відповідно до мети і об'єкта дослідження полягає у теоретичному обгрунтуванні необхідності інноваційного лідерства як чинника саморозвитку особистості керівника, вироблення інструментів особистісної ефективності, їх впровадження та визначення впливу сучасних інноваційних технологій на процес саморозвитку особистості. Методи дослідження: теоретико-методологічний аналіз літератури, синтез інформаційнопошукових концепцій, контент-аналіз наукових праць, метод групування інформації та узагальнення наукової літератури, періодичних видань та джерел інформації мережі Інтернет, систематизації інформації; аналіз і синтез, абстрагувуання, системний, структурний, структурно-функціональний. Новизна дослідження полягає в обгрунтуванні необхідності здійснення керівником функцій інноваційного лідера i поєднання розвитку професійних та особистісних якостей в умовах цифрової цивілізації.
\end{abstract}

Ключові слова: керівник, лідер, саморозвиток особистості, інновації, технології, розвиток, впровадження, управління, саморозвиток, цифровізація 
Постановка проблеми у загальному вигляді та її зв'язок із важливими науковими чи практичними завданнями

Актуальність дослідження полягає у тому, що сучасний розвиток цивілізації сприяє появі не тільки нових видів товарів і послуг, але i багато в чому впливає на трансформацію соціальноекономічної сфери суспільства. В умовах інтеграції у світову економіку необхідно постійно підтримувати належний рівень конкурентоспроможності

керівника, виробляти сучасні стратегії і навички для розкриття при хованого потенціалу та наполегливо працювати над його підвищенням, застосовуючи сучасні методи модернізації [1]. В цьому випадку керівник виступає не лише керуючим департаментом/організацією, а й лідером інновацій та змін, стосовно удосконалення діяльності організації, результатом якого має бути налагоджена керована система та відповідні їй позитивні якісні зміни, для забезпечення яких необхідний відповідний рівень менеджменту, культури, організації.

Впровадження інновацій в сфері управління $\epsilon$ вагомою конкурентною перевагою i забезпечує стійкий ефективний розвиток та стає вирішальним фактором успіху в умовах, коли конкуренція між організаціями впевнено набуває форми змагання в сфері управління знаннями. Для того, щоб підтримувати належний рівень конкуренції, лідер повинен приймати інноваційні рішення та застосовувати новітні технології, розширювати свідомість, мислити креативно, керувати стресом i часом, стати енергійнішим для досягнення мети.

В менеджменті, процес створення інноваційних методів не менш важливий, ніж технологічні інновації, оскільки підвищити продуктивність вже неможливо лише збільшенням кількісних показників. Нововведення в сфері управління позитивно впливають на спосіб та ефективність функціонування організації, використовувати ідеальні секрети ідеального тайм-менеджменту. Провідними представниками інноваційного розвитку є США, Японія та деякі країни Західної Європи. Для активації розвитку інноваційної діяльності в Україні слід взяти до уваги досвід інших країн, розробивши стратегію розвитку та переглянувши особливості державного управління, вирішити першочергові завдання для зростання інноваційного потенціалу, створивши, таким чином, сприятливі умови для залучення капіталовкладень в інноваційну сферу, для чого розвивати креативне мислення i теорію креативності.

Для забезпечення інноваційного розвитку країни необхідно створювати інноваційні структури. Яскравим прикладом є Німеччина, де працює більше ніж 200 інноваційно-технологічних центрів, в Китаї більше 15 років реалізується програма інноваційно- 
технологічного розвитку країни, відкрито близько 100 технопарків, в кожному 3 яких функціонує декілька інноваційних центри, створюючи умови для підтримки інноваційного підприємництва.

Концепція

«відкритих інновацій», коли нові цікаві ідеї розробляються за межами відомих компаній, зараз широко розповсюджується. Наприклад, «Procter \& Gamble» розвиває співпрацю 3 університетами, постачальниками

та
винахідниками, які не працюють в даній компанії, пропонуючи їм винагороду. Менш ніж за 10 років доля «сторонніх» ідей, що застосовуються у виробництві нових товарів «Р\& G», зросла 320 до $50 \%$. На думку керівництва компанії, це стимулювало інноваційний процес i становило основну причину росту об'єму виробництва. Можна привести безліч прикладів 3 досвіду відомих організацій, коли інновації в сфері управління створили вагомі конкурентні переваги для сучасного бізнесу. General Electric змінила підхід до порядку i дисципліни праці в сфері наукових досліджень, що дало змогу отримати доступ до великої кількості технологій та патентів. Саме інноваційні технології системи управління персоналом дозволяють налагоджувати та підтримувати взаємозв'язки між підрозділами та забезпечувати ефективну діяльність організації в цілому [2].

Аналіз останніх досліджень i публікацій, 3 яких започатковано розв'язання даної проблеми і на які спирається автор

У своєму дослідженні ми спираємося на роботи Андрюкайтене Регіни, Л.Верещагіної, В.Воронкової, Н.Герелюса, Т.Калістратової, О.Кивлюк, С.Сапи, С.Стукалова, О.Фурсіна, в яких мова йде про інноваційні технології в управлінні персоналом, навчанні працівників як запоруки процвітання компанії, та умов, як стати інноваційним лідером та впровадити зміни в умовах системних змін. Авторка спирається на авторські дослідження $з$ означеної теми.

Виділення

раніше частин проблеми, котрим присвячусться означена стаття

Інноваційний лідер - керівник нового типу у сучасній організації, так як лідерство в сучасному світі трансформується. Сучасний лідер це не диктатор, а той, хто надихає, він не дає готових рішень, а дозволяє своїй команді розробити їх самостійно, тим самим дозволяючи долучатися до процесу управління організацією у відповідальні моменти. Лідерство базується не на повноваженнях, а на щирому визнанні вкладу співробітників, повазі та їх досягненнями. Згідно 3 сучасними тенденціями розвитку суспільства, лідерство набуває нової форми прояву i засноване на розумінні своєї місії, знанні своїх сильних i слабких сторін, а також докладанні максимальних

зусиль 
формування та розвитку ефективної команди, що знаходиться у процесі безперервного удосконалення.

Мета статті: теоретичне обгрунтування інноваційної діяльності як чинника саморозвитку особистості керівника.

Завдання наукового доробку та формування цілей статті:

- дослідити місце і роль керівника як стратегічного лідера команди;

- з'ясувати розвиток особистості керівника як інноваційного лідера нового типу;

- виявити напрями інноваційної діяльності як чинника саморозвитку керівника в умовах системних змін та сформувати програму саморозвитку особистості керівника;

- обгрунтувати інноваційні технології у сфері менеджменту та необхідність їх впровадження в умовах smart-суспільства.

\section{Методи}

дослідження: теоретико-методологічний аналіз літератури, синтез інформаційнопошукових концепцій, контентаналіз наукових праць, метод групування інформації та узагальнення наукової літератури, періодичних видань та джерел інформації мережі Інтернет, систематизації інформації; аналіз i синтез, абстрагувуання, системний, структурний, структурнофункціональний, синергетичний.

Виклад основного матеріалу дослідження 3 обгрунтуванням отриманих наукових результатів
1. Місце і роль особистості керівника як стратегічного лідера команди

Стрімкі технологічні інновації, ринкові зміни, глобалізація економіки, розвиток електронного бізнесу сприяє появі нового типу лідера, ключовою відмінністю якого полягає в тому, що керівник постійно транслює інноваційні варіанти розвитку організації у майбутньому. Але впровадженням змін займається не тільки керівник організації i топ-менеджери, але i рядові співробітники. Досвід, який нагромадили усі члени організації, стає основою для роботи всіх працівників. Ніхто не розпочинає роботи 3 нуля. Перспективи розвитку організації залежать від керуючої системи та іiі здатності i схильності до саморозвитку, що сприяє

удосконаленню безперервному діяльності організації i дає можливість забезпечити економічний розвиток та ефективність в умовах кризи, для чого: відстежування відхилень процесів, фіксація і вивчення всіх відхилень, розв'язання проблем у процесі швидкодійних циклів, здобування i поширення нових знань.

Основним чинником, який здійснює вплив на тенденції розвитку організації виступає готовність та здатність менеджера швидко опановувати та ефективно впроваджувати нововведення. Треба зауважити, що це стосується не лише нового обладнання чи технології виробництва, але й економічних, організаційних та 
управлінських інновацій, які безпосередньо здійснюють вплив на перспективи розвитку менеджменту організації та його діяльності в цілому. Безперервне оновлення обладнання та реалізація інноваційних технологій як в сфері управління, так і виробництва, значно підвищать рівень конкурентоспроможності

організації, бо справжня мета - це створення визначних продуктів [3].

Інтенсивний розвиток організації залежить від рівня професіоналізму управління, який передбачає не тільки висококваліфіковану i професійну підготовку керівника, але i забезпечення відповідної освіти лінійних менеджерів, робітників та всіх учасників виробничого процесу. Впровадження системи розвитку персоналу, які включають різні форми підвищення кваліфікації, наукові конференції, тренінги, стажування у провідних компаніях України та за іiі межами, які дають можливість опанувати нові технології та навички, призведуть до заохочення всіх способів самовираження працівників [1]. Інновації необхідні в будь-якій сфері діяльності, особливо це стосується сфери бізнесу. В умовах сучасного розвитку цивілізації від їх вдалого впровадження залежить успіх i стабільність організації. Однак у процесі змін керівник може зіштовхнутися 3 неготовністю колективу до їх впровадження. Таким чином, керівник виступає лідером інновацій та змін в організації та має прокласти новий шлях до успіху.

Інновації - це продукт інноваційної діяльності, який втілився у вигляді удосконалених або створення нових послуг чи продукції, технологічних процесів, способів виробництва та його організації, нових ринків та просування продукції/послуги [4]. Приклад Google - лише один 3 можливих рецептів успіху. Знайти свою спеціалізацію, свій шлях і свої методи, залучити «креативних розумників» i працювати, не покладаючи рук. Головними критеріями інновації $\epsilon$ керованість та відповідність бізнес-стратегіям організації. Грамотне впровадження змін дозволить стати їм не тільки частиною організації, але й частиною менталітету колективу. Вони безпосередньо впливають на якість створюваної продукції/послуг, розвиток організації та сприяе іiі стабільності на ринку. Зараз згенеровано глобальну кількість нових ідей, але проблема полягає в правильному виборі та раціональному впровадженні. Це можливо в тому випадку, коли в колективі $\epsilon$ командний дух, постійно відбувається обмін досвідом та ідеями, а працівники впевнені, що всі зміни, які відбуваються - на краще. Топ-менеджер інноваційної компанії має добре знати предметну галузь, бути чудовим комунікатором і передавачем інформації.

Для того, щоб робітники сприймали інновації позитивно, вони повинні бути абсолютно 
впевненими в тому, що керівнику (інноваційному менеджеру), який проявляе ініціативу, можна довіряти без жодних вагань. Підлеглі довіряють тому керівнику, який зумів сформувати позитивний імідж особистості в очах персоналу [5]. Приклади сучасних інноваційних лідерів - Річард Бренсон, Стів Джобс, Майкл Делл, Ларрі Еллісон, Сем Волтон, Есте Лаудер, Джек Уелч, Сергій Брін та ін. [6]. «Креативним керівникам» потрібне середовище, яке живить i стимулює їхню творчість. Найважливіша функція менеджерів корпорації нового, інноваційного типу - пошук i залучення правильних людей, «креативних розумників», але шукають таланти всі члени команди. Справжній керівник повинен займати позицію як формального, так і неформального лідера, який володіє здатністю прогнозувати, надихати i вести за собою команду, слідкувати за розвитком інноваційних процесів та впроваджувати їх в організацію, бо кожна людина - творець, тож допомагаючи працівникам розвивати їхні творчі здібності, слід створити в організації атмосферу творчості і свободи.

\section{2. Розвиток} особистості керівника як інноваційного лідера нового типу

Інноваційний лідер - це керівник нового типу, який завжди на крок попереду. Він $\epsilon$ спеціалістом в галузі економіки, завжди готовий працювати в умовах невизначеності та досягати поставлених цілей, працюючи над
НОВИМ

асортиментом продукції/послуги та бізнес-ідеями i використовувати переваги технологічних інновацій для розвитку організації. Інноватор тісно співпрацює 3 командою, надихає підлеглих, безперервно працює над собою, удосконалюючи професійні навички. Не дивлячись на динамічну мінливість економічного середовища, готовий вирішувати складні завдання та підтверджувати високий рівень компетенції.

Лідери нового типу відрізняються витримкою, наполегливістю, стресостійкістю та, на відміну від традиційного, повинні: безперервно займатися саморозвитком (особливо це стосується високотехнологічних сфер, в яких постійно оновлюється продукція і з'являється нова, що вимагає швидкої реакції на зміни); розуміти механізми інноваційної діяльності та спільно виробляти найкращі рішення; слідкувати за науковими відкриттями, цікавитися новими технологіями та виробляти інструменти своєї творчої креативності; займатися стратегічними завданнями, а вирішення другорядних питань делегувати підлеглим, транслювати цінності і зразки бажаної поведінкирозвивати

самоврядування, що базується на синергії, відкритості довірі, відповідальності кожного [11].

Ефективне управління організацією пов'язане 3 двома фундаментальними поняттями керівник і лідер. Формальна владна позиція, яка не має відношення до 
особистісних якостей людини - це керівництво, а лідерство - це комплексне поняття, яке включає в себе асоціацію 3 особистісними рисами, взаємовідносинами, неформальною позицією керівника колективу, що передбачає здатність вести за собою i як результат колективне досягнення поставлених цілей Більшість сучасних глобальних корпорацій орієнтовані на відповідальність, інновації та меритократію («владу гідних»). Керівництво і лідерство однаково важливі поняття для управління організацією. Проте, досить часто лідерські та управлінські функції в колективі чи організації розділяються між різними людьми. Лідер (зокрема, неформальний), мотивуючи, здійснює вплив на працівників в сфері поведінки шляхом підсилення або нівелювання особистісних рис. В добре організованих групах лідер частіше використовує такі форми звернення до колективу як порада чи прохання, а форма наказу вживається значно рідше. Головна умова - це формування організації як живого організму [12].

Керівник - це офіційно призначена особа на керівну посаду, обов'язки якої передбачають функції організації і координації роботи підлеглих відповідно до посадових обов'язків. Взаємодія 3 підлеглими відбувається в межах поставлених завдань. Керівник наділений повноваженнями, які дозволяють приймати рішення і зобов'язують нести відповідальність за наслідки, що дає можливість істотно впливати на трудовий колектив, через який здійснюється безпосередній вплив на характер, функціонування організації та очікувані результати. Головні стурктурні принципи децентралізація, самоврядування i скорочення планово-контрольних функцій. На практиці не завжди можна зустріти бажане поєднання керівника і лідера в одній особі. В позиціях лідера і керівника можна спостерігати як спільні, оскільки вони дуже близькі за психологічною сутністю, так і відмінні риси. Але повного збігу не спостерігається. Різниця обумовлюється тим, що керівник частіше орієнтується на завдання спільної діяльності, а лідер - на задоволення інтересів конкретної групи, щоб здійснювати місію орагнізації. Слід зауважити, що керівник формує кадрову політику за своєю подобою, наприклад, авторитетний керівник оточує себе висококваліфікованими

спеціалістами, які добре знають свою справу, а слабкий - ще слабшими підлеглими. В першому випадку, керівник, забезпечуючи кадрову політику професіоналами, прагне розвитку i ефективної діяльності об'єкта управління, а в іншому - неефективна діяльність, результатом якої може бути занепад об'єкта управління, у контексті якого людина - це особистість, яка гідна поваги, а організація - це цілісність і визнання цінності всіх працівників.

Враховуючи те, що ми зараз живемо в час динамічного розвитку 
цивілізації і цифровізації суспільства, сьогодення висуває свої умови для тих, хто прагне займати лідерські позиції і зовсім неважливо в якій галузі. Представники різних ланок управління повинні йти в ногу 3 часом, оскільки вони очолюють організації і виступають гарантами успіху i ефективності діяльності об’єкта управління, який побудований на принципах децентралізації й відповідальності iii членів. Концепція «керівниклідер», яка передбачає поєднання формального керівництва i неформального лідерства має здійснити позитивний ефект на діяльність трудового колективу i організації в цілому. Поняття «керівник» і «лідер» не тотожні, але при бажанні i докладанні максимальних зусиль, а іноді, навіть, і більше, можна досягти такого бажаного поєднання. Перш за все, це вимагає неабиякої підготовки, яка дозволить застосувати на практиці, i вміння утримати цю позицію, яка вимагає безперервного розвитку i укріплення своїх знань в сфері діяльності та управління, відвідуючи навчальні курси/тренінги, читаючи літературу, практикуючись в психології, оскільки сучасний керівник повинен бути i психологом для того, щоб мати змогу розбиратися в людях, їх можливостях і взаємовідносинах в трудовому колективі, адже успіх керівника-лідера залежить від правильно підібраної команди. Невід'ємною складовою керівника- лідера $є$ постійний розвиток лідерських здібностей, не зупинятися на досягнутому, оскільки час не стоїть на місці i суспільство

безперервно розвивається. Колектив буде цінити i поважати керівника, який буде іти в ногу 3 колективом і вносити свій вклад в загальний результат, працюючи над проєктами, виробляючи стійкість, що слугує ознакою величі компанії.

Окрім спеціальних здібностей i задатків, провідну роль відіграють розумові та фізичні властивості, а також особливі особистісні дані, які дозволяють мотивувати людей, направляти їх на виконання спільної роботи. Це можливо лише в тому випадку, коли керівник постійно працюе над собою, удосконалюючи себе як особистість. Бути відкритими до нових знань i поглядів на світ, робити ставку на розвиток людського і соціального капіталу, адже головний капітал великих компаній - це люди. У великих компаній завжди талановиті керівники ті, для яких активне застосування новаторських, ретельно дібраних складних технологій та людей стимулюють зростання компанії.

3. Інноваційна діяльність як чинник саморозвитку керівника в умовах системних змін та програма саморозвитку особистості керівника

Ефективність роботи організації залежить від здатності керівника створити умови, які забезпечать гармонічний розвиток кожного 
робітника. Для цього необхідне постійне самовдосконалення управлінської культури керівника, який $€$ гарантом створення сприятливих умов для творчої діяльності колективу. Необхідність безперервної освіти і саморозвитку сучасного керівника набирає обертів [7]. Саморозвиток - це самостійне набуття знань 3 різноманітних джерел, враховуючи інтереси та схильності конкретної людини. Як процес оволодіння знаннями він тісно пов'язаний 3 самовихованням і вважається його складовою частиною.

Саморозвиток керівника - це процес активної боротьби 3 власною інтелектуальною бідністю. 3 одного боку, це безперервне збагачення своїх професійних знань, а 3 іншого - постійне оновлення і переосмислення свого власного досвіду і вилучення того, що втратило свою актуальність 3 часом [7].

\section{Програма}

саморозвитку керівника не може обмежуватися лише вузьким колом спеціальної літератури та обміном досвіду. Вона повинна включати удосконалення

знань, ознайомлення 3 досягненнями науки, техніки і літератури. Тобто, розвиток особистості керівника повинен бути комплексним, включаючи різні джерела інформації та знань [7]. Керівник зобов'язаний завжди бути в курсі останніх новацій, пов'язаних 3 конкретною сферою діяльності, зокрема. Досвідчене керівництво організації має знати всі тонкощі іiі функціонування зважаючи на динаміку вимог ринку.

Відвідування різноманітних культурних, освітніх заходів і самоосвіта допоможуть підтримувати необхідний рівень професійних знань керівника [8]. Форми саморозвитку керівника: репродуктивні (практикуми, науково-практичні семінари, тренінги); репродуктивноевристичні (науково-практичні конференціi); евристичні (проблемні та проблемно-проєктні семінари, ситуаційні ігри); евристично-продуктивні

(фестивалі, конкурси професійної майстерності і методичних розробок); продуктивні (наукові конференції, семінари, наукові стажування, участь в роботі тимчасових науководосліджувальних колективах, тимчасових творчих групах). Для того, щоб постійно підтримувати належний рівень конкурентоспроможності і займати найвищі позиції в конкурентній боротьбі, керівник має відповідати заданим компетенціям і володіти певними професійними якостями. Адже, справжній лідер - це еталон, професіонал своєї справи, той, за ким хочеться слідувати і в кого переймати досвід.

Основні кроки щодо здійснення програми саморозвитку особистості керівника:

Крок 1. Аналіз і планування

Перш ніж зайнятися саморозвитком, треба проаналізувати свої здібності/навички. Визначитися які якості подобаються, а які навпаки. 
Чого не вистачає та чого іще хотілося б додати?

Проведений аналіз допоможе скласти план дій. На перший погляд це здається складним завданням, але треба починати 3 найменшого.

Крок 2. «Холодний розум»

Треба вміти контролювати свої емоціï! Завжди викликають захоплення люди, які в найскладнішій ситуації до всього підходять 3 холодним розумом, а їх терпінню в конфліктній ситуації можна лише позаздрити. Але! В той самий час вони палко мотивують i запалюють свою команду на спільну перемогу.

Крок 3. Отримання, фільтрація, застосування знань

На сьогоднішній день існує безліч способів отримання інформації: книги, відеопортали, аудіокниги, лекції, тренінги, семінари, 3МI, інтернет-ресурси, спілкування 3 колегами, однодумцями і т. д. Але разом $з$ тим збільшується ризик отримання недостовірної інформації, а іноді, навіть, шкідливої. Саме тому вміти фільтрувати потік інформації $\epsilon$ досить важливою здібністю, особливо для успішного керівника. Для того, щоб інформація була корисною, треба навчитися правильно іiі сприймати.

Крок 4. Ораторське мистецтво

Необхідним і важливим умінням для керівника-лідера $\epsilon$ ораторське мистецтво. Професійний оратор повинен володіти наступними якостями:

- грамотна, чітка мова;

- вміння викладати думки;
- вміння тримати себе на публіці;

- вміння утримувати увагу публіки.

Це стане в нагоді в будь-якій ситуації (сцена чи нарада, переговори чи бесіда тет-а-тет)

Крок 5. Уміння працювати в команді і $з$ командою

Для своєї команди лідер повинен бути прикладом. В свою чергу, членам команди необхідно знати, що їх розуміють, відчувають, цінують.

Крок 6. Навчитися бути незамінним

Часто поняття «незамінний» плутають 3 приховуванням інформації. Працівнику 3 такою життєвою позицією не стати лідером, управлінцем. Небажання ділитися інформацією чи досвідом може зробити незамінним лише на короткий проміжок часу, оскільки рано чи пізно хтось обійде в умінні та майстерності. Бути незамінним це означає, що треба постійно розвиватися в своїй професійній діяльності і показувати відмінні результати в роботі. Незамінність працівника стає відчутною, коли його немає на робочому місці (відпустка чи лікарняний), що відображається на результатах роботи департаменту чи всієї організації. Для цього необхідно володіти неабиякими здібностями, талантом і везінням.

Крок 7. Відкинути будь-які сумніви

Досить часто лідер $\epsilon$ уособленням впевненості i 3 цим неможливо не погодитися. Потрібно бути впевненим в собі і у 
всьому, що ви робите. Під час виступу перед великою аудиторією, від вас повинна випромінюватися впевненість, навіть якщо почуваєтеся інакше. Особливо це стосується ситуації, коли треба визнати помилку. Сильна, впевнена в собі людина не соромиться визнати свою помилку, навіть, на публіці, тому що не помиляється той, хто нічого не робить. А вміння виявити помилку в своїх діях i визнати ऑii наслідки вчинок розумної і впевненої в собі людини [9]. Постійно слід удосконалюватися, у всіх сферах життя використовувати правило ПІНВ - постійно і невпинно вдосконалюватися. Зміцнювати здоров'я, розвивати пам'ять, ерудицію, інтелект. Втілювати 10 заповідей успіху: 1) взяти відповідальність на себе; 2) приборкати страх; 3) поставити мету; 4) скласти план; 5) діяти; 6) контролювати; 7) вірити в успіх; 8) саморозвиватися; 9) створювати стосунки і комунікації; 10) удосконалюватися.

\section{4. Інноваційні технології сфері менеджменту та необхідність їх впровадження в умовах smart-суспільства}

Інтенсивний

розвиток

інформаційних технологій сприяє розширенню трудової мобільності, державної служби та інших сфер діяльності, необхідних сучасному суспільству, тим самим підіймаючи рівень розвитку країни. Інформаційне суспільство характеризується безперервним розвитком, що обумовлений значними об'ємами інформаційних джерел. Зважаючи на важливість інформаційних комунікацій, стрімке вдосконалення інформаційно-системних

технологій та їх вплив на сфери життєдіяльності людини, можна впевнено сказати, що соціальна сфера під впливом еволюційної трансформації переходить на новий рівень - smart-суспільство. Smartсуспільство побудоване таким чином, що «розумна» робота, яка утворена «розумним» життям, державою і бізнесом, базується на «розумній» інфраструктурі і «розумних» громадянах, які відіграють провідну роль у створенні smart-культури, яка $\epsilon$ складовою частиною інформаційної культури, медіакультури, на яких грунтується та розвивається i сприяє розвитку людини як творця інноваційного середовища $[10,11]$.

Використовуючи сучасні електронні технології, ми формуємо нове високоосвічене суспільство, що призводить до цифровізації всіх сфер діяльності. Застосування інноваційних технологій в системі менеджменту $\epsilon$ вагомою конкурентною перевагою, забезпечує стійкий ефективний розвиток підрозділу та всієї організації. Інновації та інноваційні технології виконують функцію підтримки впровадження та використання певних нововведень. Іншими словами, інновація - це технологія, яка дозволяє мінімізувати витрати i підвищити продуктивність праці. Удосконалення - це безперервний процес звуження фокусу до 
маленького елементу успіху, повторення його доти, доки ви не засвоїти навички, а потім використання цієї нової звички, щоб перейти до наступного етапу розвитку.В системі управління під поняттям «нововведення» слід розуміти будь-які організовані рішення, системи, процедури або методи управління, які принципово відрізняються від існуючої звичної практики i вперше застосовується на практиці в конкретній організації.

Фактори, які вказують на необхідність впровадження інноваційних технологій в сфері менеджменту наступні: зниження темпів розвитку виробництва; економічний спад; зниження витрат на персонал; зниження показників виробітку; зростання плинності кадрів. Крім зазначених факторів, передумовами впровадження інновацій також можуть бути тенденції розвитку організації та галузей економіки, необхідність зниження витрат на кадрову систему i підвищення конкурентоспроможності

організації. Не давати технологіям заволодіти вашим життям, приборкувати їх, перетворювати на ефективний інструмент досягнення цілей.

Інформаційні технології в управлінні персоналом спрямовані на вирішення таких завдань: впровадження сучасних комп'ютерних технологій в процес збирання і аналізу даних; створення віртуального офісу - системи прямого доступу i активної взаємодії людей, які знаходяться віддалено один від одного. В якості основних технологій, заснованих на застосуванні

програмного забезпечення і програмних додатків можна виділити: віддалений доступ i онлайн-взаємодія для вирішення типових завдань в сфері менеджменту: співбесіда через Skype, заповнення електронних бланків анкет, трансляція електронних копій персональних документів, дистанційне навчання i т.д.; створення баз даних обліку i контролю кадрової статистики (трудової дисципліни, динаміки кадрового складу, аналізу якості персоналу і т.д.); проведення відеоконференцій і вебінарів 3 участю працівників віддалених підрозділів; каскадування важливої інформації (новин) на особисту електронну пошту працівників; розвиток інтерактивних додатків внутрішньої мережі для оперативного збору зворотнього зв'язку, розвитку участі працівників в обговоренні значущих проблем [4]. Лише п'ять секунд відділяють будь-яку людину від першого кроку: використовувати силу волі i правило п’яти секунд, щоб діяти.

Таким чином, інноваційні технології в сфері менеджменту являють собою способи більше ефективного управління компетенціями і детермінантами компетенцій, кадровими процесами і положеннями об'єкту управління. Інноваційна активність персоналу залежить від кадрової політики, яка грунтується на практиці навчання персоналу, виявленні та утриманні найбільш ініціативних працівників, 
заохоченні їх самостійності i високої результативності. Використовувати принцип піраміди Мінто: правильно складений текст має форму піраміди, де ідеї з'єднані вертикальними i горизональними зв'язками, а на їх iii вершині вміщено головне твердження. Впровадження інновацій в сфері управління персоналом призводять до змін в інших ресурсних сферах: в характері продукції/послуги, створеної об'єктом управління, в способі побудови взаємовідносин 3 партнерами та конкурентами, в діяльності організації в цілому. Розуміння актуальних тенденцій розвитку управління персоналом та впливу на людину призводить до прориву організації

$\mathrm{y}$
висококонкурентному середовищі та створення іiі унікальних компетенцій i властивостей. В основі численних методика впливу на людину лежать шість психологічних принципів впливу: 1) принцип обміну; 2) принцип дефіциту; 3) принцип авторитету; 4) принцип послідовності; 5) принцип соціального доказу; 6) принцип інновації.

Мета саморозвитку - це формування найбільш ефективного стилю управління, який максимально гармонізує 3 особистістю, допомагає досягти потрібних цілей i при цьому позбавлений стресів і дискомфорту. Мета саморозвитку керівника це коли з ним співпрацюють, коли панує синергія у колективі і має місце взаєморозуміння 3 колективом, керівник завжди дає оцінку всьому, що відбувається, вміє приймати оптимальні рішення.

\section{Висновки 3 дослідження i перспективи подальших розвідок у цьому напрямі}

Сучасний розвиток цивілізації сприяе появі не тільки нових видів товарів і послуг, але і багато в чому впливає на трансформацію соціально-економічної сфери суспільства. В умовах інтеграції в світову економіку необхідно постійно підтримувати належний рівень конкурентоспроможності та наполегливо працювати над його підвищенням, застосовуючи сучасні методи модернізації. Згідно сучасним тенденціям розвитку суспільства, лідерство набуває нової форми прояву і засноване на розумінні своєї місії, знанні своїх сильних і слабких сторін, а також докладання максимальних зусиль для формування та розвитку проактивної команди. Проактивні люди керуються цінностями i вміють підпорядковувати свої імпульсивні реакції.

Стрімкі технологічні інновації, ринкові зміни, глобалізація економіки, розвиток електронного бізнесу сприяє появі нового типу лідера, ключовою відмінністю якого полягає в тому, що керівник постійно транслюе інноваційні варіанти розвитку організації у майбутньому. Ваш головний інструмент - ви самі, і ваш стан безпосередньо визначає, на що ви здатні. Справжній керівник повинен займати позицію як формального, так і неформального лідера, який володіє здатністю 
прогнозувати, надихати i вести за собою команду, слідкувати за розвитком інноваційних процесів та впроваджувати їх в організацію. Креативність - здатність інтелекту створювати нове, осмислювати незвідане, i ця здатність може виявитися у будь-яки й момент, адже життя не лінійне, а циклічне і можна повернутися у будь-яку його очку будь-якої миті. Людина господар свого життя, до мети веде безліч шляхів, але треба вибирати найкоротший. 20\% зусиль дають $80 \%$ результатів.

Інноваційний лідер - це керівник нового типу, який завжди на крок попереду. Він $\epsilon$ спеціалістом в галузі економіки, завжди готовий працювати в умовах невизначеності та досягати поставлених цілей, працюючи над новим асортиментом продукції/послуги та бізнес-ідеями i використовувати переваги технологічних інновацій для розвитку організації. Концепція «керівник-лідер», яка передбачає поєднання керівництва i неформального лідерства має здійснити позитивний ефект на діяльність трудового колективу і організації в цілому. Використовувати «правило трьох»: три досягнення на день, три на тиждень, три на місяць і три на рік. Невід'ємною складовою керівника-лідера $\epsilon$ постійний розвиток лідерських здібностей, не зупинятися на досягнутому, оскільки час не стоїть на місці i суспільство безперервно розвивається. Колектив буде цінити і поважати керівника, який буде іти в ногу 3 колективом і вносити свій вклад в загальний результат, працюючи над проєктами. Якщо ви щось дізналися, прочитали, з'ясували - застосовуйте відразу. Саморозвиток керівника - це процес активної боротьби 3 власною інтелектуальною бідністю. 3 одного боку, це безперервне збагачення своїх професійних знань, а 3 іншого - постійне оновлення і переосмислення свого власного досвіду і вилучення того, що втратило свою актуальність 3 часом.

Керівник зобов'язаний завжди бути в курсі останніх новацій, пов'язаних 3 конкретною сферою діяльності, зокрема. Досвідчене керівництво організації має знати всі тонкощі ऑi функціонування зважаючи на динаміку вимог ринку. Відвідування різноманітних культурних, освітніх заходів і самоосвіта допоможуть підтримувати необхідний рівень професійних знань керівника. Використовувати тайм-драйв: ставте мету, плануйте, дійте, мотивуйте i заохочуйте себе, організовуйте інформацію, відпочивайте. В системі управління під поняттям «нововведення» слід розуміти будь-які організовані рішення, системи, процедури або методи управління, які принципово відрізняються від існуючої звичної практики i вперше застосовується на практиці в конкретній організації. Розвивати систему чотирьох переліків важливих справ: перелік ідей, перелік проєктів, перелік тижневих справ, перелік справ найважшливіших на день. 


\begin{tabular}{lrll}
\hline Фактори, які & \multicolumn{2}{c}{ вказують на } & все навколо творчо, підживлювати \\
необхідність & впровадження & свої творчі ресурси, спілкуйтеся 3 \\
iнноваційних технологій в сфері & успішними людьми, усвідомлювати \\
менеджменту: & зниження темпів & свою унікальність і унікальність \\
розвитку & виробництва; & інших людей, щодня виробляйте \\
економічний спад; зниження витрат & свідомість успіху, можливості \\
на персонал; зниження показників & Всесвіту безмежні i його \\
виробітк; з зростання плинності & подарунків вистачить на всіх.
\end{tabular}

\section{СПИСОК ВИКОРИСТАНОЇ ЛІТЕРАТУРИ}

1. Стародубець В. С. Тенденции развития менеджмента промышленных предприятий в Украине. Міжнародна науково-практична конференція теорія $i$ практика: проблеми та перспективи - 2019 : матеріали міжнар. наук.-практ. конф., м. Маріямполе, 9-10 трав. 2019 р. Маріямполе, 2019.

2. Стукалов C. А. Инновационные технологии в управлении персоналом. URL: http://e-koncept.ru/2016/56769.htm

3. Герелюс Н.I. (2017). Менеджмент в Україні: стан та перспективи розвитку. Сучасний менеджмент: витоки, реалї̈ та перспективи розвитку : зб. тез наук.-практ. конф., м. Дубляни, 2017 р. С. 3-5.

4. Верещагіна Л. С. До питання про розвиток інноваційних технологій в персоналменеджменті. URL: https://cyberleninka.ru/article/n/k-voprosu-o-razvitii-innovatsionnyhtehnologiy-v-personal-menedzhmente/viewer

5. Менеджмент інновацій: як впровадити зміни в компанію. URL: https://premiummanagement.com/blog/vnedrenie-innovacij

6. Бути інноваційним лідером - як це? URL: https://www.executive.ru/education/glavy-iz-knig/1949723-byt-innovatsionnym-liderom-kakovo-eto

7. Калістратова T. O. Самоосвіта i самовдосконалення керівника. URL: https://nsportal.ru/detskiy-sad/upravlenie-dou/2019/06/11/samoobrazovanie-isamosovershenstvovanie-rukovoditelya-dou

8. Навчання працівників i саморозвиток керівника - запорука процвітання компанії. URL: https://loftville.ru/obuchenie-rabotnikov-i-samoobrazovanie-rukovoditeljazalog-procvetanija-kompanii/

9. Саморозвиток лідера : 7 важливих кроків. URL: https://hr-tv.ru/articles/authoropinion/samorazvitie-lidera-7-vazhnyh-shagov.html

10.Воронкова В. Г. Кивлюк О. П., Андрюкайтене Регіна. Антропологічні виміри смарт-суспільства: теоретико-концептуальний досвід. Гуманітарний вісник Запорізької державної інженерної академії: зб.наук.пр. 2018. Вип. 73. С. 25-38.

11. Воронкова В. Г., Фурсін О. О., Сапа Н.В., 2011. Соціально-орієнтоване державне управління.: монографія. Запоріжжя: РВВ ЗДІА. $256 \mathrm{c.}$

12. Воронкова В.Г. Муніципальний менеджмент: навч. посіб.. Київ: Професіона. 2004.

13. Олексенко Р. И., Гостева Н. П. Экономический механизм государственного регулирования туристической отрасли Украины. Современный научный вестник. 2013. Т. 13. №. 152. С. 5-15.

14. Андрюкайтене, Р. М., Олексенко, Р. І., Чумак, Т. В. Управління навчальним закладом як концептуальна засада творення нової української школи. Особистісно-професійний розвиток вчителя умовах реалізації концепції нової

(с) Стародубець В.С., 2020 
української школи: Всеукраїнська науково- практична конференція 3 міжнародною участю, Мелітополь, 14-16 червня 2018, Мелітополь: 2018. 116-18.

15. Олексенко Р. И. Рыночные отношения в современном философскоэкономическом дискурсе. Новый университет. Йошкар-Ола. 2013. С. 22.

\section{REFERENCES}

1. Starodubets V.S., 2019. Tendentsii razvitiya menedzhmenta promyishlennyih predpriyatiy v Ukraine. MIzhnarodna naukovo-praktichna konferentsIya teoriya i praktika: problemi ta perspektivi - 2019 : materIali mIzhnar. nauk.-prakt. konf., m. MarIyampole, 9-10 trav. 2019 r. MarIyampole.

2. Stukalov S. A., 2016. Innovatsionnyie tehnologii v upravlenii personalom. URL: http://e-koncept.ru/2016/56769.htm

3. Gerelyus N. I., 2017. Menedzhment v UkrayinI : stan ta perspektivi rozvitku. Suchasniy menedzhment: vitoki, realiyi ta perspektivi rozvitku : zb. tez nauk.-prakt. konf., m. Dublyani, 2017 r. S. 3-5.

4. VereschagIna L. S. Do pitannya pro rozvitok InnovatsIynih tehnologIy v personalmenedzhmentI. URL: https://cyberleninka.ru/article/n/k-voprosu-o-razvitii-innovatsionnyhtehnologiy-v-personal-menedzhmente/viewer

5. Menedzhment InnovatsIy : yak vprovaditi zmIni $\mathrm{v}$ kompanIyu. URL: https://premiummanagement.com/blog/vnedrenie-innovacij

6. Buti innovatsiynim liderom - yak tse? URL: https://www.executive.ru/education/glavy-iz-knig/1949723-byt-innovatsionnym-liderom-kakovo-eto

7. Kalistratova T. O. Samoosvita i samovdoskonalennya kerivnika. URL: https://nsportal.ru/detskiy-sad/upravlenie-dou/2019/06/11/samoobrazovanie-isamosovershenstvovanie-rukovoditelya-dou

8. Navchannya pratsIvnikiv i samorozvitok kerivnika - zaporuka protsvitannya kompaniyi. URL: https://loftville.ru/obuchenie-rabotnikov-i-samoobrazovanie-rukovoditeljazalog-procvetanija-kompanii/

9. Samorozvitok lidera : 7 vazhlivih krokiv. URL: https://hr-tv.ru/articles/authoropinion/samorazvitie-lidera-7-vazhnyh-shagov.html

10. Voronkova V. H., Kivlyuk O.P., Andryukaytene Regina, 2018. AntropologichnI vimiri smart-suspIlstva: teoretiko-kontseptualniy dosvid. GumanItarniy visnik Zaporizkoyi derzhavnoyi inzhenernoyi akademiyi: zb.nauk.pr. Vip. 73. 25-38.

11. Voronkova V. H., Fursin O. O., Sapa N.V., 2011. Sotsialno-orientovane derzhavne upravlinnya.: monografiya. Zaporizhzhya: RVV ZDIA. $256 \mathrm{~s}$.

12. Voronkova V. H., 2004. Munitsipalniy menedzhment: navch. posib. Kiyiv: Profesional. 2004.

13. Oleksenko R. Y., Hosteva N. P., 2013. Эkonomycheskyi mekhanyzm hosudarstvennoho rehulyrovanyia turystycheskoi otrasly Ukraynы. Sovremennыi nauchnыi vestnyk. T. 13. №. 152. S. 5-15.

14. Andriukaitene, R. M., Oleksenko, R. I., Chumak, T. V. , 2018. Upravlinnia navchalnym zakladom yak kontseptualna zasada tvorennia novoi ukrainskoi shkoly. Osobystisno-profesiinyi rozvytok vchytelia umovakh realizatsii kontseptsii novoi ukrainskoi shkoly: Vseukrainska naukovo- praktychna konferentsiia $\mathrm{z}$ mizhnarodnoiu uchastiu, Melitopol, 14-16 chervnia 2018, 16-18.

15. Oleksenko R. Y., 2013. Rыnochnыe otnoshenyia v sovremennom fylosofskoэkonomycheskom dyskurse. Novыi unyversytet. Yoshkar-Ola. 22. 
Стародубец, В. С. - магистрант специальности 073 «Менеджмент»

Инженерного учебно-научного института Запорожского национального университета

(Запорожье, Украина)

E-mail: starodubecviktoria@gmail.com

ORCID iD: http://orcid.org/0000-0003-0395-2675

\title{
SELF-DEVELOPMENT OF THE PERSONALITY OF THE LEADER AS A LEADER OF INNOVATION IN THE CONDITIONS OF SYSTEM CHANGES
}

\begin{abstract}
The urgency of the work is that globalization and the dynamic development of modern society have led to the emergence of "smart-society" as a smart and high-tech, characterized by continuous development of innovations, the active implementation of which has a great impact on economy, production, culture, education, life., social sphere, scientific research. Innovation management and interaction with existing innovative technologies become integral components of organization management as a socio-economic system and subsystems in the form of structural units that require creative workers who are able to work in a competitive environment. The aim of the research is the theoretical substantiation of innovative activity as a factor of self-development of the leader's personality. Tasks of research and formation of the purposes of article: to investigate a place and a role of the head as the strategic leader of a team; to find out the development of the leader's personality as a new type of innovative leader; identify areas of innovation as a factor in the self-development of the leader in terms of systemic change and form a program of self-development of the leader's personality; to substantiate innovative technologies in the field of management and the need for their implementation in a smart society. The object of research is the personality of the leader as a leader of innovation and change in the context of systemic change. The task in accordance with the purpose and object of research is to theoretically substantiate the need for innovative leadership as a factor in self-development of the leader, the development of tools for personal effectiveness, their implementation and determine the impact of modern innovative technologies on self-development. Research methods: theoretical and methodological analysis of literature, synthesis of information retrieval concepts, content analysis of scientific works, method of grouping information and generalization of scientific literature, periodicals and sources of information on the Internet, systematization of information; analysis and synthesis, abstraction, systemic, structural, structural-functional. The novelty of the study lies in the justification of the need for the head to perform the functions of an innovative leader and a combination of professional and personal qualities in a digital civilization.
\end{abstract}

Keywords: leader, leader, personal self-development, innovations, technologies, development, implementation, management, self-development, digitalization

Стародубец, В. С. - магистрант специальности 073 «Менеджмент»

Инженерного учебно-научного института Запорожского национального университета (Запорожье, Украина)

E-mail: starodubecviktoria@gmail.com

ORCID iD: http://orcid.org/0000-0003-0395-2675

\section{САМОРАЗВИТИЕ ЛИЧНОСТИ РУКОВОДИТЕЛЯ КАК ЛИДЕРА ИННОВАЦИЙ В УСЛОВИЯХ СИСТЕМНЫХ ИЗМЕНЕНИЙ}


Аннотация. Актуальность работы заключается в том, что мировая глобализация и динамичное развитие современного общества обусловили появление «smart-общества» как високорозумного и вискотехнологичного, характеризующегося непрерывным развитием инноваций, активное внедрение которых имеет большое влияние на экономику, процессы производства, культуру, образование, быт, социальную сферу, научные исследования. Управление инновационной деятельностью и взаимодействие с существующими инновационными технологиями становятся неотъемлемыми компонентами управления организацией как социально-экономической системой и подсистемами в виде структурных подразделений, требуют креативных работников, способных работать в конкурентоспособной среде. Целью исследования является теоретическое обоснование инновационной деятельности как фактора саморазвития личности руководителя. Задача исследования и формирования целей статьи: исследовать место и роль руководителя в качестве стратегического лидера команды; выяснить развитие личности руководителя как инновационного лидера нового типа; выявить направления инновационной деятельности как фактора саморазвития руководителя в условиях системных изменений и сформировать программу саморазвития личности руководителя; обосновать инновационные технологии в сфере менеджмента и необходимость их внедрения в условиях smart-общества. Объектом исследования выступает личность руководителя, как лидера инноваций и изменений в условиях системных изменений. Задача соответствии с целью и объекта исследования состоит в теоретическом обосновании необходимости инновационного лидерства как фактора саморазвития личности руководителя, выработки инструментов личностной эффективности, их внедрение и определение влияния современных инновационных технологий на процесс саморазвития личности. Методы исследования: теоретикометодологический анализ литературы, синтез информационно-поисковых концепций, контент-анализ научных работ, метод группировки информации и обобщение научной литературы, периодических изданий и источников информации сети Интернет, систематизации информации; анализ и синтез, абстрагувуання, системный, структурный, структурно-функциональный. Новизна исследования заключается в обосновании необходимости осуществления руководителем функций инновационного лидера и сочетание развития профессиональных и личностных качеств в условиях цифровой цивилизации.

Ключевые слова: руководитель, лидер, саморазвитие личности, инновации, технологии, развитие, внедрение, управление, саморазвитие, цифровизация

Received date 01. 12.2020

Accepted date 11.12.2020

Published date 21.12.2020 